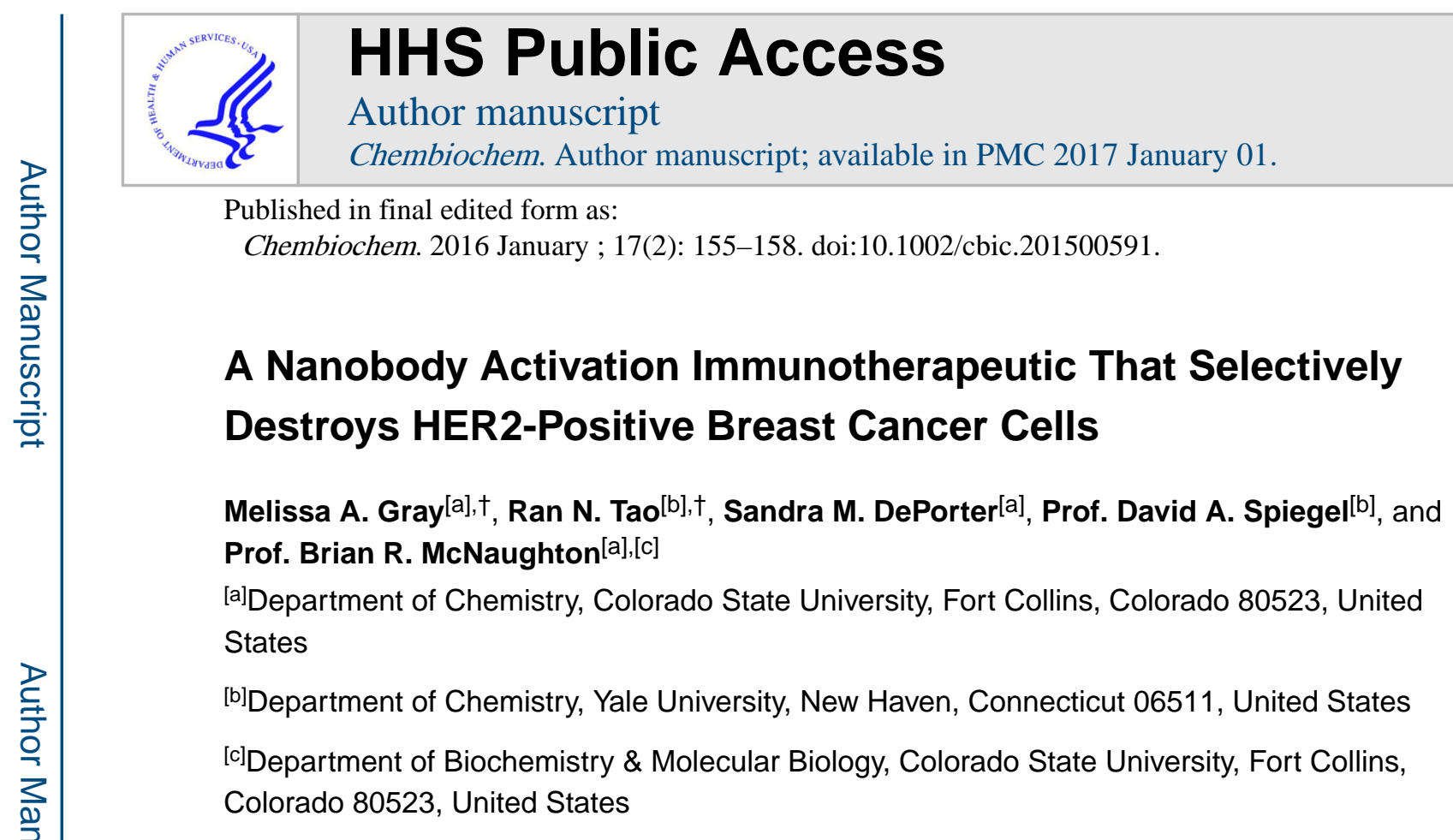

\begin{abstract}
We report a rationally designed nanobody activation immunotherapeutic that selectively redirects anti-dinitrophenyl (anti-DNP) antibodies to the surface of HER2-positive breast cancer cells, resulting in their targeted destruction by antibody-dependent cellular cytotoxicity. Since nanobodies are relatively easy to express, stable, can be humanized, and can be evolved to potently and selectively bind virtually any disease-relevant cell surface receptor, we anticipate broad utility of this therapeutic strategy.
\end{abstract}

\title{
Killer nanobody
}

We report a rationally designed nanobody activation immunotherapeutic that selectively redirects anti-dinitrophenyl antibodies to the surface of HER2-positive breast cancer cells, resulting in their targeted destruction by antibody-dependent cell cytotoxicity.

Correspondence to: Brian R. McNaughton.

$\dagger_{\text {both authors contributed equally }}$

Supporting information for this article is given via a link at the end of the document. 


\section{rationally engineered protein \\ targets destruction of HER2-positive breast cancer cells}

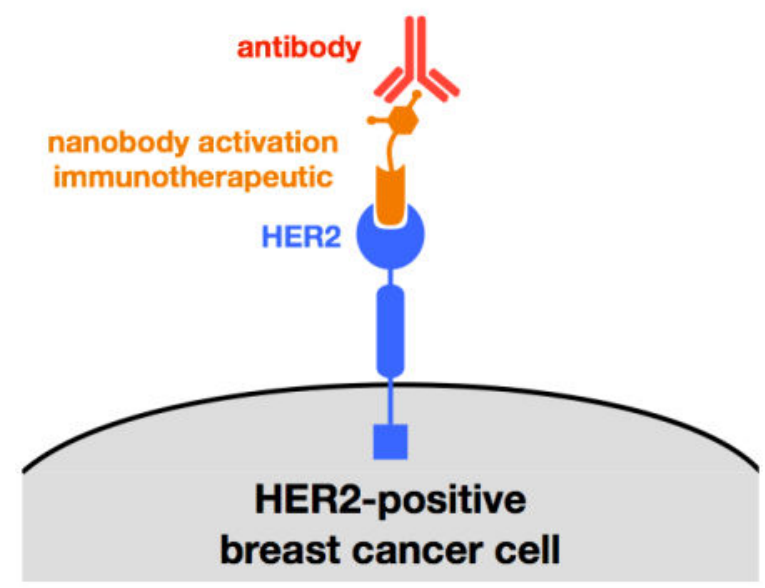

\section{Keywords}

activation immunotherapeutic; nanobody; immunotherapy; breast cancer; HER2

Current proteinaceous cellular probes and therapeutics (including 10 of the 20 top selling prescription drugs in Q4 $2013^{[1]}$ ) demonstrate their remarkable ability to modulate diseaserelevant cell function and fate. Historically, the therapeutic mechanisms of action of proteinbased reagents (principally antibodies) has been limited to recognition of a cell surface receptor. For example, Trastuzumab ${ }^{[2]}$ (marketed as Herceptin ${ }^{\mathrm{TM}}$ ), is an FDA-approved monoclonal antibody that works by binding to $\underline{H} u m a n$ Epidermal growth factor $\underline{\text { Receptor }} \underline{2}$ (HER2 ${ }^{[3]}$ ), a protein overexpressed on the surface of $\sim 20-30 \%$ of breast cancers and $\sim 20 \%$ of gastric cancers. ${ }^{[4]}$ Overexpression of HER2 is correlated to aggressive phenotypes and poor patient prognosis. ${ }^{[5]}$ Additionally, dye conjugation to an antibody that selectively binds a disease-relevant cell surface receptor can identify diseased cells, but a more powerful strategy would be to couple recognition of a disease-relevant cell surface receptor to destruction of the bound cell.

Activation immunotherapeutics are designed to elicit or amplify an immune response, resulting in destruction of specific (labeled) diseased cells. ${ }^{[6]}$ Antibody-Recruiting Molecules (ARMs) are a recently reported example of activation immunotherapeutics. ${ }^{[7]}$ These chimeric molecules consist of two chemically linked, but functionally orthogonal components (Figure 1a). The Cell Binding Domain (CBD) selectively binds a diseaserelevant cell surface receptor, while the Antibody Recruiting Domain (ARD) binds to an endogenous antibody, recruiting it to the targeted cell surface.

Dinitrophenyl (DNP) has previously been used as an ARD reagent. ${ }^{[8]}$ Antibodies recognizing the DNP epitope have been estimated to constitute $\sim 1 \%$ of circulating IgM and $\sim 0.8 \%$ of circulating $\operatorname{IgG}^{[9]}$, likely resulting from exposure to DNP-containing dyes, preservatives, and/or pesticides. ${ }^{[9 \mathrm{~b}]}$ Alone, DNP is insufficient to incite immune-mediated 
cytotoxicity. However, when conjugated to a CBD, a high effective molarity of the DNP reagent on the cell surface can trigger immune-mediated cytotoxicity (Figure 1b), including antibody-dependent cellular cytotoxicity (ADCC), antibody-dependent cellular phagocytosis (ADCP), or complement dependent cytotoxicity (CDC). ${ }^{[7-8]}$

In many ways, proteins are particularly well suited to serve as the cell-binding component within an activation immunotherapeutic platform. The relatively large size, well-defined structure and functional group diversity found in proteins often allows these structures to potently and selectively bind macromolecular surfaces that challenge-or entirely evadesmall-molecule drug discovery. Additionally, high-throughput molecular biology-based screening and evolution-based methods (principally phage ${ }^{[10]_{-}}$, yeast ${ }^{[11]_{-}}$, bacterial ${ }^{[12]_{-}}$, and $\mathrm{mRNA}^{[13]}$-display) often make the identification of new protein binders (including proteins that bind a cell surface receptor) substantially simpler than the analogous small molecule discovery process. Finally, the potency and selectivity profiles of protein drugs often exceed their small molecule counterparts.

In an effort to rationally engineer a protein as an activation immunotherapeutic-to selectively induce antibody-dependent cellular cytotoxicity—we used a previously described nanobody that selectively binds HER2 with excellent affinity (dissociation constant, $K_{\mathrm{D}}$ $\sim 510 \mathrm{pM}$ ). ${ }^{[14]}$ This HER2-binding nanobody (referred to as 5F7 herein) is a camelid-derived protein, which has many features that are well suited for therapeutic utility. For example, unlike monoclonal antibodies, nanobodies are typically produced in large amounts in bacterial expression systems, are small in size ( $\sim 15 \mathrm{kDa})$, and are usually very stable and thus amenable to modification, evolution (to recognize a different target), and protein engineering. ${ }^{[15]}$ Nanobodies can also be humanized by mutating a small number of residues $^{[16]}$, and often bind their target with excellent affinities $\left(K_{\mathrm{D}} \sim 0.1-100 \mathrm{nM}\right)$ and selectivity profiles through interactions involving well-defined antigen binding loops (Figure 2a, binding loops are labelled in green); since the structure of the HER2-binding nanobody 5 F7 has not been reported the structure of a GFP-binding nanobody ${ }^{[17]}$ is shown as a representative example of nanobody structure and placement of antigen binding loops.

The rational construction of a HER2-binding nanobody activation immunotherapeutic is shown in Figure 2a. Using standard molecular biology techniques, we prepared a 5F7 variant that contains a flexible and soluble $\mathrm{N}$-terminal (GGS) ${ }_{4}$ linker, lipoic acid ligase acceptor peptide (LAP tag ${ }^{[18]}$ ) and C-terminal His 6 tag. This protein is referred to as LAP-5F7 herein. LAP-5F7 was expressed in E. coli and purified on nickel-NTA. The modified 5F7 nanobody was then selectively conjugated to carboxylic acid-aldehyde $\mathbf{1}$, using a previously reported strategy ${ }^{[19]}$, by the action of a lipoic acid ligase mutant ( ${ }^{\mathrm{W} 371}$ LpIA). This aldehydefunctionalized HER2-binding nanobody was then reacted with 50 molar equivalents of DNP hydrazine 2 to generate the DNP-functionalized nanobody (referred to as DNP-5F7 herein). Following removal of excess DNP hydrazine by dialysis, DNP conjugation on the 5F7 nanobody was verified by mass spectrometry and Western blot: we observe a mass that is consistent with the DNP-conjugated nanobody (Supporting Information, Figure S1); the DNP-conjugated nanobody is also detected by a commercially available anti-DNP antibody (Figure 2b, lane 3). In contrast, the unconjugated nanobody is not recognized by the same anti-DNP antibody (Figure 2b, lane 2). DNP conjugation via the hydrazone is stable under 
physiological conditions. When DNP-5F7 is incubated in phosphate buffered saline at $37{ }^{\circ} \mathrm{C}$, we observe no significant protein degradation or loss of DNP over 48 hours (Supporting Information, Figure S2).

Conjugation to the N-terminus of $5 \mathrm{~F} 7$ does not dramatically alter the affinity or selectivity of HER2-recognition. When high HER2 expressing SK-BR-3 breast cancer cells are treated with a solution containing $500 \mathrm{nM}$ eGFP-5F7 fusion protein, then washed to remove unbound material, the cells exhibit observable levels of cell surface-bound GFP (Figure 3a). In contrast, when the same fusion protein is incubated with MCF-7 or MDA-MB-231 breast cancer cells-which express lower levels of cell surface HER2—no observable cell surface fluorescence is observed (Supporting Information, Figure S3). DNP conjugation to 5F7 results in exogenous anti-DNP antibody recruitment, and in a manner that is selective for HER2-positive breast cancer cells. We observe high levels of SK-BR-3 cell fluorescence following incubation with $500 \mathrm{nM}$ DNP-5F7 and Alexa Fluor® 488-labelled anti-DNP antibodies. (Figure 3b). In contrast, when SK-BR-3 cells are first treated with HER2targeting siRNA, leading to decreased cellular levels of HER2 as determined by Western blot and flow cytometry (Supporting Information, Figures S4 and S5), we observe $\sim 75 \%$ lower cellular fluorescence, indicating that much lower levels of Alexa Fluor ${ }^{\circledR} 488$-labelled anti-DNP antibody are recruited to the cell surface. In addition, we did not observe appreciable levels of fluorescently-labelled anti-DNP on the surface of HER2-negative MCF7 and MDA-MB-231 cells, following incubation with DNP-5F7. The effect, or lack thereof, of DNP conjugation on cell surface HER2 recognition was quantitatively assessed by flow cytometry. DNP-5F7 binds HER2-positive SK-BR-3 cells with a half maximal effective concentration $\left(\mathrm{EC}_{50}\right.$ ) of $\sim 7.14 \mathrm{nM}$. LAP-5F7, which lacks DNP, is not recognized by anti-DNP antibody (Figure 3C).

Having established that (1) fusion to the N-terminus of 5F7 does not appreciably suppress HER2 recognition, and (2) that enzymatic conjugation of DNP to 5F7 results in cellselective recruitment of anti-DNP antibodies, we tested the ability of DNP-5F7 to induce antibody-dependent cellular cytotoxicity of SK-BR-3 breast cancer cells. This process is known to take place by way of interactions between Fc receptors on cytotoxic immune effector cells contained in peripheral blood (such as NK cells, macrophages, and dendritic cells) and the Fc regions of antibodies. Thus, SK-BR-3 cells were combined with peripheral blood mononuclear cells (PBMCs), anti-DNP antibodies, and DNP-5F7, and cell death was measured using a commercially available lactate dehydrogenase (LDH) release assay (Figure 4). As expected, we observe a concentration-dependent increase in ADCC in response to DNP-5F7 treatment (Figure 4, blue line). The half maximal effective concentration $\left(\mathrm{EC}_{50}\right)$ of $\mathrm{ADCC}$ is approximately $60 \mathrm{nM}$. In contrast, treatment with LAP-5F7 (which lacks any conjugated DNP) did not significantly alter cell viability (Figure 4, red line). Additionally, when low HER2-expressing MB-MDA-231 cells were treated with PBMCs, anti-DNP antibodies, and DNP-5F7, no appreciable cell death was observed (Figure 4, purple line). In the absence of anti-DNP antibodies (Figure 4, green line) or PBMCs (Figure 4, orange line), DNP-5F7 itself does not induce cell death. Collectively, these data indicate that cell cytotoxicity is selective, and dependent upon the level of cell surface displayed HER2. 
In summary, we have reported a nanobody activation immunotherapeutic (DNP-5F7). This reagent was constructed through enzymatic and chemical methods, and is capable of selectively binding to HER2-positive breast cancer cells and recruiting anti-DNP antibodies to the cell surface. When HER2-positive SK-BR-3 breast cancer cells are co-treated with peripheral blood mononuclear cells, anti-DNP antibody, and DNP-5F7, we observe antibody-dependent cellular cytotoxicity at concentrations in the sub-micromolar range. In contrast, antibody dependent cellular cytotoxicity of low HER2-expressing breast cancer cells by this reagent is not observed. Since high-throughput screening and evolution-based approaches can be used to generate nanobodies that potently and selectively bind virtually any disease-relevant cell surface receptor, we anticipate broad utility of these reagents. Efforts toward this end, as well as optimization of the linker and antibody-recruiting component are currently underway and will be reported in due course.

\section{Experimental Section}

\section{Construction of DNP-5F7}

Protein expression and purification-Cells were grown in $0.5 \mathrm{~L} \mathrm{LB}$ cultures containing carbenicillin at $30^{\circ} \mathrm{C}$ to $\mathrm{OD}_{600}=\sim 0.6$ and induced with $1 \mathrm{mM} \mathrm{IPTG}$ at $25{ }^{\circ} \mathrm{C}$ for $12 \mathrm{~h}$. Cells were then collected by centrifugation, resuspended in equal parts B-PER and Tris lysis buffer ( $25 \mathrm{mM}$ Tris, $100 \mathrm{mM} \mathrm{NaCl}, \mathrm{pH} 7.4)$ and stored at $-20^{\circ} \mathrm{C}$. Frozen pellets were thawed and sonicated for $2 \mathrm{~min}$. The lysate was cleared by centrifugation $(8000 \mathrm{rpm}, 20$ min) and the supernatant was mixed with Ni-NTA agarose resin $(1 \mathrm{~mL})$ for $1 \mathrm{~h} \mathrm{at} 4{ }^{\circ} \mathrm{C}$. The resin was collected by centrifugation $(4750 \mathrm{rpm}, 5 \mathrm{~min})$ and washed $1 \times 40 \mathrm{~mL}$ buffer containing $25 \mathrm{mM}$ imidazole, followed by $1 \times 10 \mathrm{~mL}$ with buffer containing $40 \mathrm{mM}$ imidazole. Proteins were then eluted with $8 \mathrm{~mL}$ buffer containing $400 \mathrm{mM}$ imidazole. Next, the proteins were dialyzed against buffer and analyzed for purity. Enzymatic Conjugation of Aldehyde Linker: In $5 \mathrm{~mL}$ total reaction volume ${ }^{\mathrm{W} 37 \mathrm{~L}} \mathrm{LplA}(1 \mu \mathrm{M})$, ATP $(5 \mathrm{mM}$, from 100 $\mathrm{mM}$ stock solution, $\mathrm{pH}$ 7), Aldehyde linker (1 mM, from $200 \mathrm{mM}$ stock in filtered DMSO), and LAP-5F7 $(20 \mu \mathrm{M})$ were added to sodium phosphate reaction buffer $\left(25 \mathrm{mM} \mathrm{Na}_{2} \mathrm{PO}_{4}, 5\right.$ $\mathrm{mM} \mathrm{Mg}(\mathrm{OAc})_{2}, \mathrm{pH}$ 7.2). The reaction was shaken at $200 \mathrm{rpm}$ at ambient temperature for 2 h. Following this, the buffer was exchanged and excess reagents were removed on a $10 \mathrm{kDa}$ ultracentrifugation concentrator by washing and concentrating the reaction $3 \times \mathrm{PBS}(\mathrm{pH}$ 5.2). TOF MS (m/z): Calculated for $[\mathrm{M}+\mathrm{H}]+, 16227.7$; Found 16228.4. 5F7-Aldehyde Reaction with DNP: Immediately following the enzymatic conjugation of the aldehyde moiety, the LAP-5F7 conjugate was concentrated in PBS (pH 5.2). In a total reaction volume of $2.5 \mathrm{~mL}$, DNP hydrazine ( $2 \mathrm{mM}$, from a $1 \mathrm{M}$ stock in DMSO), and aniline (40 $\mathrm{mM})$ were added to the $5 \mathrm{~F} 7$ conjugate $(40 \mu \mathrm{M})$. The reaction was put on a rotator overnight at $4{ }^{\circ} \mathrm{C}$. The reaction was then washed and the buffer exchanged for PBS (pH 7.4) with several washing and concentrating steps in a $10 \mathrm{kDa}$ MWCO ultracentrifugation concentrator. TOF MS (m/z): Calculated for $[\mathrm{M}+\mathrm{H}]+$, 16408.5; Found 16408.4.

\section{Antibody-dependent cellular cytotoxicity (ADCC) assay}

High HER2-expressing (SK-BR-3) or low HER2-expressing (MB-MDA-231) target cells were plated at 10,000 cells per well in black clear bottom 96-well plates in growth media $\left(100 \mu \mathrm{L}\right.$ per well) and incubated at $37^{\circ} \mathrm{C}$. Frozen peripheral blood mononuclear cells 
(PBMCs) were thawed, resuspended at $1 \mathrm{e} 6$ cells per $\mathrm{mL}$ in assay buffer, and incubated at $37^{\circ} \mathrm{C}$. After $12-24 \mathrm{~h}$, target cells were washed $2 \times 150 \mu \mathrm{L}$ assay buffer and then incubated with varying concentrations of DNP-5F7 or LAP-5F7 in the presence or absence of rabbit anti-dinitrophenyl IgG-KLH antibodies $(40 \mu \mathrm{g} / \mathrm{mL})$ in assay buffer at $37{ }^{\circ} \mathrm{C}$ for $1 \mathrm{~h}$, followed by addition of PBMCs (50:1 effector:target, $100 \mu \mathrm{L}$ per well final volume). Cells were incubated at $37^{\circ} \mathrm{C}$ for $4 \mathrm{~h}$, centrifuged, and the supernatant was transferred to new black clear bottom 96-well plates. LDH release was measured using the Promega Cytotox 96 NonRadioactive Cytotoxicity Assay Kit. The \% specific lysis was calculated using the formulas below:

$$
\begin{aligned}
& \% \text { lysis }=\frac{\text { experimental- effector spontaneous }- \text { target spontaneous }}{\text { target maximum-target spontaneous }} \times 100 \\
& \% \text { specific lysis }=(\% \text { lysis in presence of nanobody })-(\% \text { lysis in absence of nanobody })
\end{aligned}
$$

\section{Supplementary Material}

Refer to Web version on PubMed Central for supplementary material.

\section{Acknowledgments}

We acknowledge A. Chapman (CSU) for preparing a plasmid encoding the 5F7 nanobody, and helpful discussions. This work was funded by the Colorado Center for Drug Discovery (B.R.M.) and National Institutes of Health (D.A.S, GM100283-01).

\section{References}

1. http://www.drugs.com/stats/top100/sales.

2. McKeage K, Perry CM. Drugs. 2002; 62:209-243. [PubMed: 11790161]

3. Gutierrez C, Schiff R. Arch Pathol Lab Med. 2011; 135:55-62. [PubMed: 21204711]

4. (a) Menard S, Casalini P, Campiglio M, Pupa S, Agresti R, Tagliabue E. Ann Oncol. 2001; 12:1519.(b) Cooke T, Reeves J, Lanigan A, Stanton P. Ann Oncol. 2001; 12:23-28. [PubMed: 11249045]

(c) Cooke T, Reeves J, Lannigan A, Stanton P. Eur J Cancer. 2001; 37:S3-S10.

5. (a) Carlsson J, Nordgren H, Sjostrom J, Wester K, Villman K, Bengtsson NO, Ostenstad B, Lundqvist H, Blomqvist C. Br J Cancer. 2004; 90:2344-2348. [PubMed: 15150568] (b) Slamon DJ, Clark GM, Wong SG, Levin WJ, Ullrich A, McGuire WL. Science. 1987; 235:177-182. [PubMed: 3798106]

6. Kazemi T, Younesi V, Jadidi-Niaragh F, Yousefi M. Artif Cells Nanomed Biotechnol. 2015:1-11. [PubMed: 25297052]

7. McEnaney PJ, Parker CG, Zhang AX, Spiegel DA. ACS Chem Biol. 2012; 7:1139-1151. [PubMed: 22758917]

8. (a) Murelli RP, Zhang AX, Michel J, Jorgensen WL, Spiegel DA. J Am Chem Soc. 2009; 131:17090-17092. [PubMed: 19888723] (b) Parker CG, Domaoal RA, Anderson KS, Spiegel DA. J Am Chem Soc. 2009; 131:16392-16394. [PubMed: 19839582] (c) Zhang AX, Murelli RP, Barinka C, Michel J, Cocleaza A, Jorgensen WL, Lubkowski J, Spiegel DA. J Am Chem Soc. 2010; 132:12711-12716. [PubMed: 20726553]

9. (a) Karjalainen K, Makela O. Eur J Immunol. 1976; 6:88-93. [PubMed: 964298] (b) Farah FS. Immunology. 1973; 25:217-226. [PubMed: 4733801]

10. Smith GP, Petrenko VA. Chem Rev. 1997; 97:391-410. [PubMed: 11848876]

11. Boder ET, Wittrup KD. Nat Biotechnol. 1997; 15:553-557. [PubMed: 9181578]

12. Kenrick SA, Daugherty PS. Protein Eng Des Sel. 2010; 23:9-17. [PubMed: 19903738]

13. Wilson DS, Keefe AD, Szostak JW. P Natl Acad Sci USA. 2001; 98:3750-3755. 
14. Pruszynski M, Koumarianou E, Vaidyanathan G, Revets H, Devoogdt N, Lahoutte T, Zalutsky MR. Nucl Med Biol. 2013; 40:52-59. [PubMed: 23159171]

15. Muyldermans S. Annu Rev Biochem. 2013; 82:775-797. [PubMed: 23495938]

16. Vincke C, Loris R, Saerens D, Martinez-Rodriguez S, Muyldermans S, Conrath K. J Biol Chem. 2009; 284:3273-3284. [PubMed: 19010777]

17. Kubala MH, Kovtun O, Alexandrov K, Collins BM. Protein Sci. 2010; 19:2389-2401. [PubMed: 20945358]

18. Puthenveetil S, Liu DS, White KA, Thompson S, Ting AY. J Am Chem Soc. 2009; 131:1643016438. [PubMed: 19863063]

19. Cohen JD, Zou P, Ting AY. ChemBioChem. 2012; 13:888-894. [PubMed: 22492621] 


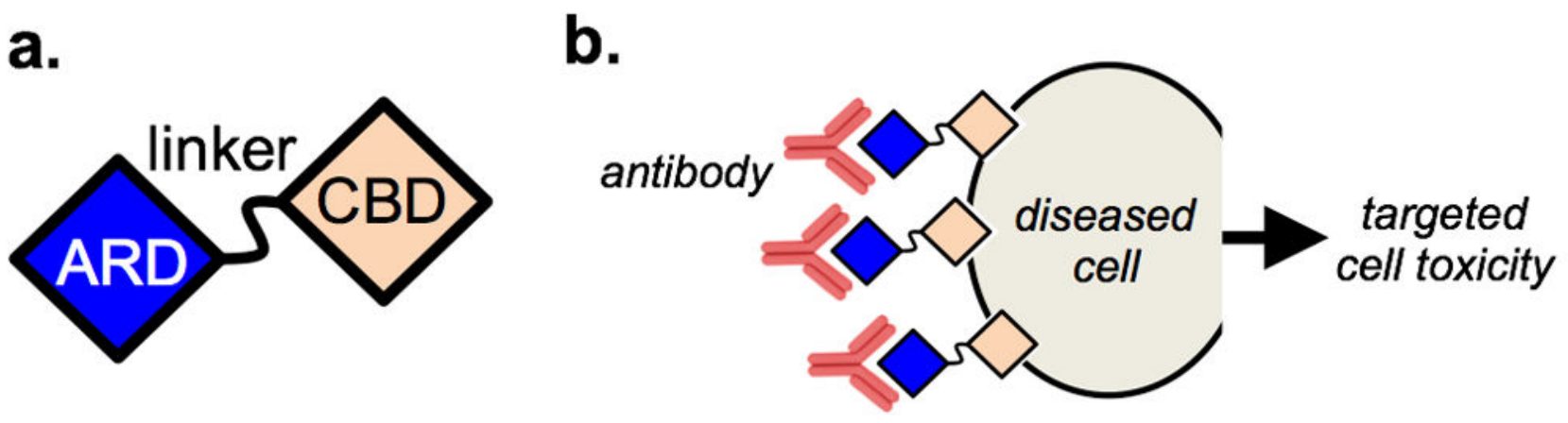

Figure 1.

(a) Architecture of an activation immunotherapeutic, which consists of a cell-binding domain (CBD) and antibody-recruiting domain (ARD). (b) The CBD of an antibody activation immunotherapeutic selectively binds to a receptor displayed on the surface of diseased cells. Recruitment of an endogenous antibody_-generating a high effective molarity of antibody on the surface of the diseased cell-leads to targeted and immune system-dependent cytotoxicity. 
a.
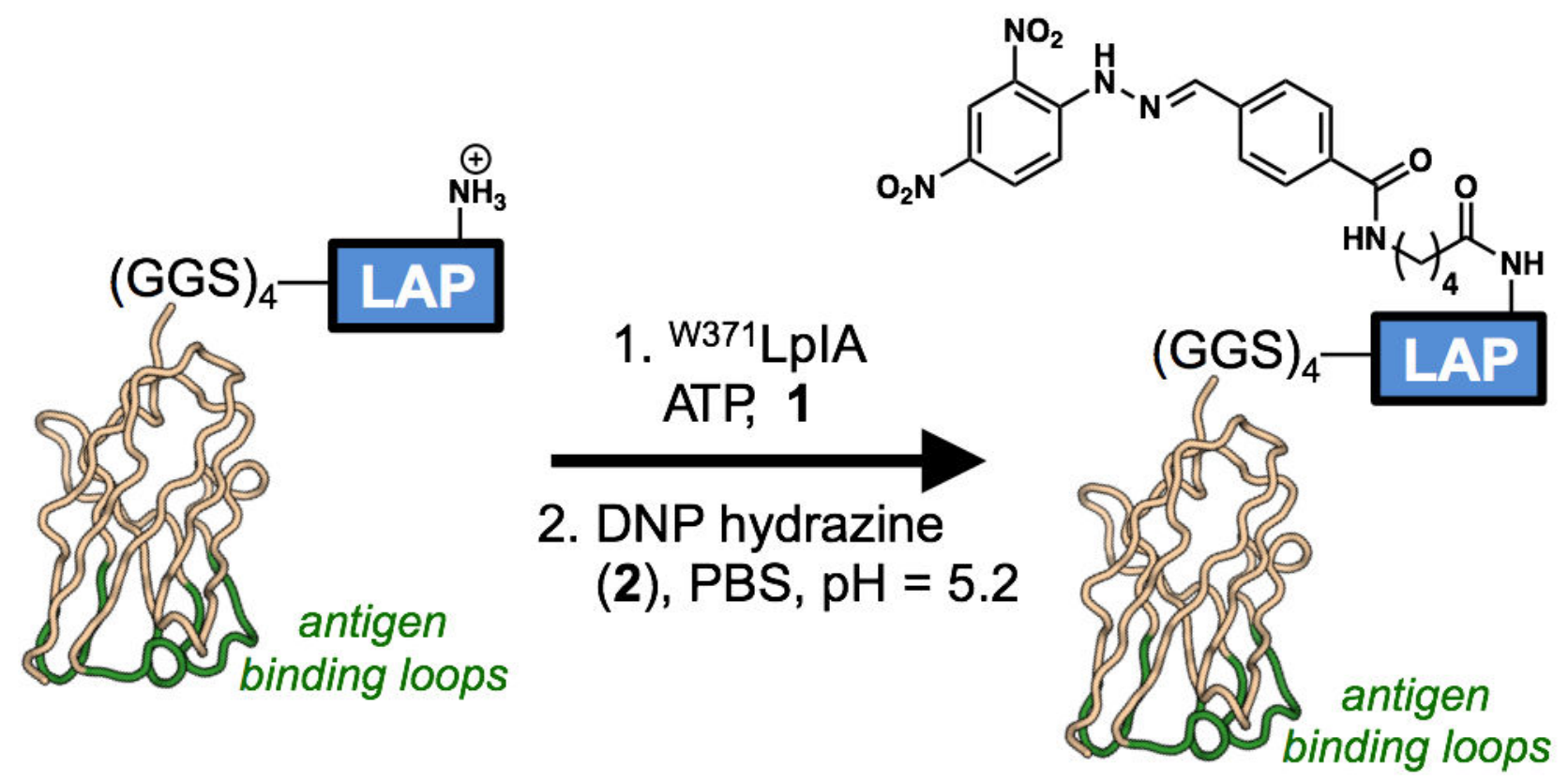<smiles>CC(C)(C)NC(=O)c1ccc(C=O)cc1</smiles>

b $\mathrm{kDa}$

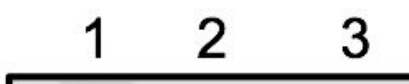<smiles>NNc1ccc([N+](=O)[O-])cc1[N+](=O)[O-]</smiles>

2

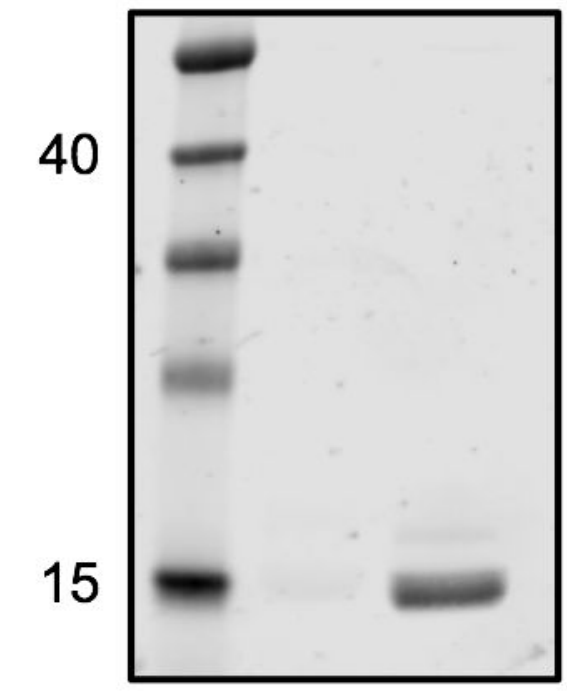

Figure 2.

(a) Nanobody conjugation to a DNP-functionalized molecule by lipoic acid ligase mutant

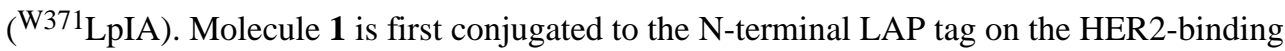
nanobody. This aldehyde-functionalized nanobody is then reacted with DNP-hydrazine 2, generating the DNP-conjugated nanobody. (b) Western blot: unconjugated nanobody is not recognized by a commercially available anti-DNP antibody (Lane 2), while conjugated protein is selectively recognized by anti-DNP antibody (Lane 3 ). 
a.

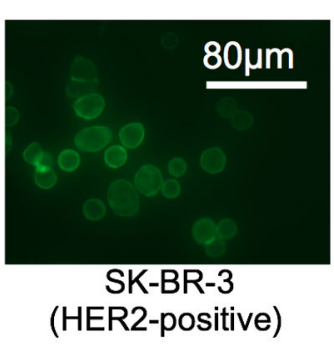

b.

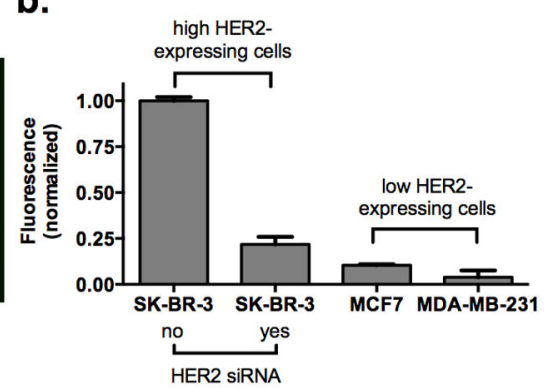

c.

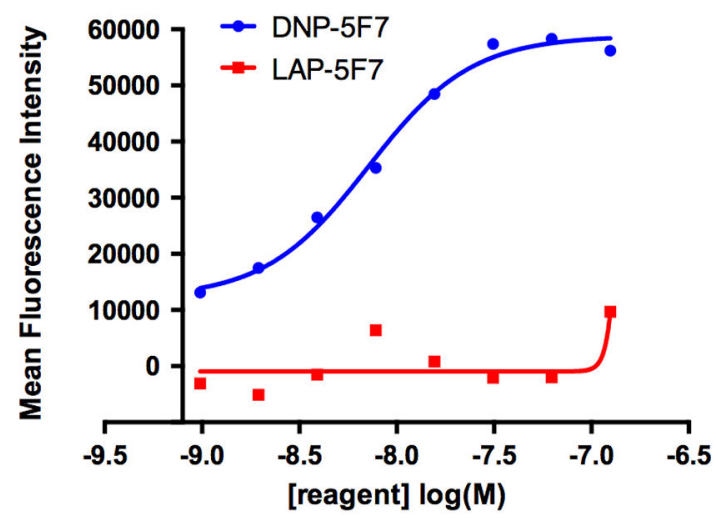

Figure 3.

(a) Fluorescence microscopy images of HER2-positive SK-BR-3 cells following treatment with 500 nM GFP-5F7. (b) Flow cytometry data showing recruitment of exogenous Alexa Fluor ${ }^{\circledR}$ 488-labelled anti-DNP antibody to HER2-positive SK-BR-3 cells, but not HER2 siRNA treated SK-BR-3 cells, and not to HER2-negative MCF7 and MDA-MB-231 cells. Error bars represent standard deviation from three replicate experiments. (c) Determination of the half maximal effective concentration $\left(\mathrm{EC}_{50}\right)$ of nanobody activation immunotherapeutic DNP-5F7 necessary to saturate recruitment of Alexa Fluor ${ }^{\circledR} 488$ labelled anti-DNP antibodies to HER2-positive SK-BR-3 breast cancer cells ( IC $_{50} \sim 7 \mathrm{nM}$, blue line). LAP-5F7 is not recognized by anti-DNP antibodies (red line). 


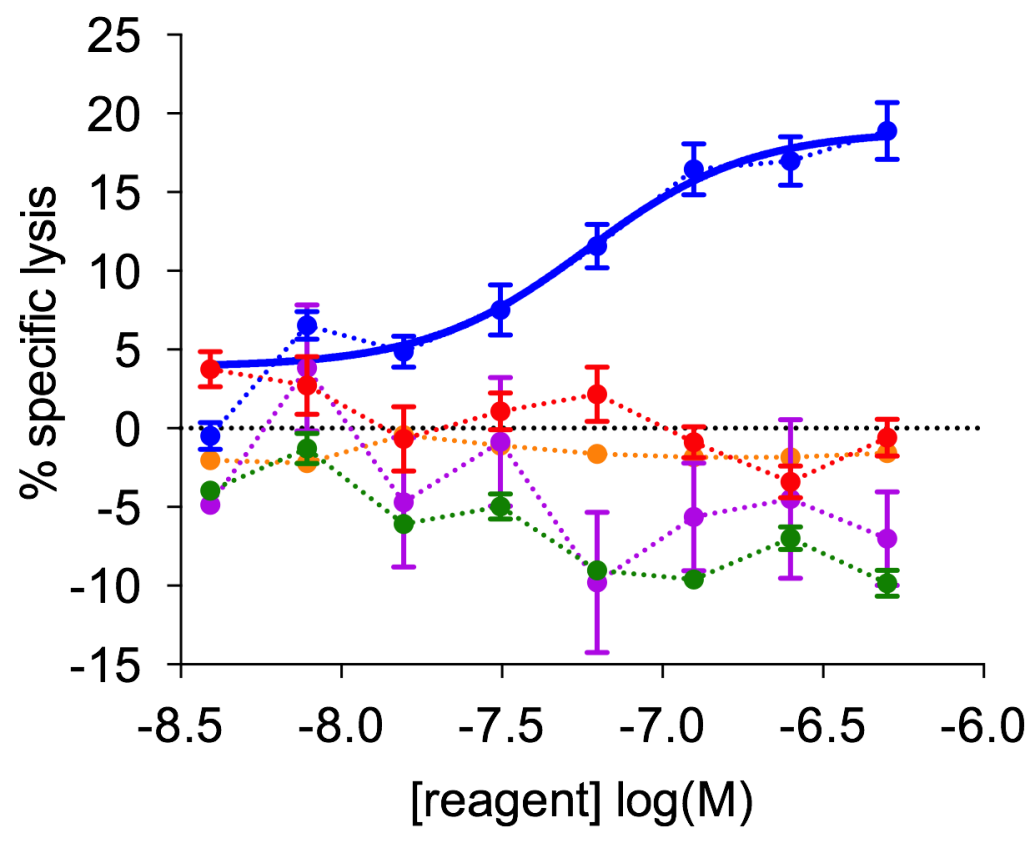

$$
\begin{array}{ll}
. \bullet & \text { 5F7-DNP + anti-DNP Ab + SK-BR-3 + PBMC } \\
. \bullet & \text { LAP-5F7 + anti-DNP Ab + SK-BR-3 + PBMC } \\
. \bullet & \text { 5F7-DNP + SK-BR-3 + PBMC } \\
. \bullet & \text { 5F7-DNP + anti-DNP Ab + MDA-MB-231 + PBMC } \\
. \bullet & \text { 5F7-DNP + anti-DNP Ab + SK-BR-3 }
\end{array}
$$

Figure 4.

Antibody-dependent cellular cytotoxicity (ADCC) of high HER2-expressing SK-BR-3 cells (blue), but not low HER2-expressing MB-MDA-231 cells (purple), triggered by the nanobody activation immunotherapeutic DNP-5F7. The unconjugated nanobody (LAP-5F7) is not toxic to SK-BR-3 cells (red). DNP-5F7 in the absence of anti-DNP antibodies (green) or PMBCs (orange) also does not trigger ADCC. Error bars represent standard error from three independent experiments. 